\title{
The Structure of Drinking-Related Consequences in Alcoholic Women
}

\author{
Joanne E. Turnbull and Edith S.L. Gomberg
}

\begin{abstract}
This study examines the structure of drinking-related consequences in women in treatment facilities by describing indices that were constructed by submitting 69 measures to factor analysis. Two hundred fifty-four (254) alcoholic women responded to self-report interview items that measured the consequences that the respondent perceived to follow or result from her drinking. The items were submitted to a series of exploratory principal component analyses. Nine factors, social withdrawal, sexuality, early effects, maternal role, accidents, symptoms, work, illness, and relationship conflict, emerged in the rotated solution, with the majority of coefficient alphas in the 0.6 to 0.8 range. Internal reliabilities for the indices remained sufficiently high across age subgroups in the sample.

Key Words: Alcoholic Women, Factor Analysis of Alcohol-Related Consequences, Structure of Alcohol-Related Consequences.
\end{abstract}

$\mathbf{T}$ HE REPORTED EXPERIENCE of adverse consequences that result from or follow excessive alcohol consumption is standard criteria for the determination of problem drinking. Drinking-related consequences are most often classified as either physical or social. Physical consequences include morbidity and mortality, and health related problems, ${ }^{1,2}$ and social consequences include problems in personal relationships, trouble with legal authorities, accidents, and employment with the past year. ${ }^{3}$ Because only recently have women been included in studies on alcohol abuse and alcoholism on a regular basis, most studies concerned with drinking-related consequences are based on those experienced by men. There is an unstated assumption that the consequences of alcohol consumption can be considered without taking gender into account despite existing evidence that suggests that drinking-related consequences are not uniform among different groups of problem drinkers. Because research has been conducted on male samples, by and large, our knowledge about consequences of drinking tends to be limited to those experienced by men. This paper examines the structure of drinking-related consequences reported by alcoholic women in treatment as a preliminary step to deter-

From the Department of Psychiatry, Duke University Medical Center, Durham, North Carolina (J.E.T.) and School of Social Work and Department of Psychiatry, University of Michigan, Ann Arbor, Michigan (E.S.L.G)

Received for publication January 9, 1990; accepted July 30, 1990.

This work was supported in part by National Institute of Mental Health Training Grant Number T32 MH16806-03 and National Institute on Alcohol Abuse and Alcoholism Grant Number 5R01 AA04143.

Reprint requests: Joanne E. Turnbull, PhD, Columbia University School of Social Work, 622 West 113th Street, New York, NY 10025.

Copyright $@ 1991$ by The Research Society on Alcoholism.

Alcohol Clin Exp Res, Vol 15, No 1, 1991: pp 29-38 mine whether or not the experience of alcoholic women is unique.

The adverse consequences reported by women may be different from those reported by men because of the unique socialization and life experiences that are specific to women, yet studies comparing men and women ignore this possibility. Consequently, the frequency and severity of alcohol-related consequences may be understated for women because the measured constructs are based on research conducted on male alcoholics and therefore misrepresent the female drinking experience. By the same token, common notions about the consequences of female drinking may be incorrect because they are based on observations of clinical samples rather than empirically derived measures. For example, the consequences of problem drinking for women are still hypothesized as most likely to be reported in the interpersonal and family realms, ${ }^{4-6}$ since problem-drinking women in clinical samples are more likely than men to cite marital instability and family problems as reasons both for problem drinking and for seeking treatment. ${ }^{7-9}$ In national surveys, however, the most common individual drinking problem reported by women is driving while intoxicated ${ }^{5}$; reports that drinking interferes with housework and family relationships are relatively rare. ${ }^{6}$ While one explanation for these incongruent reports may be the use of different samples, inconsistencies may be aggravated by the lack of standardized measures of drinking consequences developed specifically for women drinkers.

To date, the few factor analytic studies that have been conducted on samples of alcoholics have been limited to men. None of these has examined the consequences of alcoholism in either men or women directly. Factor analysis has been used to examine the structure of depression in several studies of male alcoholics, ${ }^{10-13}$ and in one study of female alcoholics conducted by the present authors. ${ }^{14}$ Only one factor analytic study approximates the present study of the structure of drinking-related consequences in women. MacAndrew (1986) ${ }^{15}$ derived four self-depiction factors from 25 items of the Minnesota Multiphasic Personality Inventory (MMPI) ${ }^{16}$ : agitated depression, familial dissatisfaction, hypersensitivity, and irreligiosity. ${ }^{15}$ In this study, alcoholic women were compared with female psychiatric outpatients who were not substance abusers, female medical outpatients, and female college students, and were found to be similar to the psychiatric outpatients and different from the other two groups. 
Additional justification for examining alcohol-related consequences specific to women comes from evidence suggesting that men and women differ not only in the amount and severity of reported consequences but also in the risk of developing specific biological and social consequences. Men are more likely than women to report moderately severe adverse consequences of drinking. ${ }^{17}$ However, while both alcoholic men and women have excessive morbidity and mortality rates, ${ }^{18-20}$ alcoholic women demonstrate higher rates of death and illness directly related to alcohol relative to duration and amount of alcohol consumption. ${ }^{21,22}$ Thus, greater adverse consequences reported by men may be related to heavier consumption levels reported by men or to the more public nature of male heavy drinking.

Depressive symptoms that follow the onset of alcoholism are related to a more severe course of alcohol problems..$^{23}$ Accordingly, comparisons of consequences of alcoholism among depressed and nondepressed alcoholics have also been the focus of research. These studies have documented an association between depressive symptoms and both physiological dependence and psychosocial concomitants of alcoholism. ${ }^{24-26}$ Research has also documented differences between depressed and nondepressed alcoholic women, ${ }^{27}$ including a positive association between depression and amount and severity of drinkingrelated consequences. ${ }^{23,28}$ For depressed alcoholic men, both marital instability, ${ }^{29,30}$ and undesirable life events have been reported. ${ }^{31}$

Clearly, our knowledge of women's alcohol problems can be enhanced by a clearer understanding of drinkingrelated consequences that are unique to women. Ideally, this issue would be best examined by a study that included a comparison group of male alcoholics to determine whether findings regarding drinking consequences for women are unique to women, more common in women than in men, or perhaps also characteristic of men. However, the construction of indices describing alcohol-related consequences that are specific to a sample of alcoholic women is an important first step.

\section{METHODOLOGY}

\section{Sample}

The original sample consisted of 301 alcoholic women who were treated for alcoholism during 1981 and 1982 in 21 different hospitals, residential treatment centers, and outpatient facilities in six counties in Southeastern Michigan. Subjects were asked to participate in a $2-\mathrm{hr}$ interview after detoxification, at least 1 week after admission. Respondents were Caucasian, primarily middle class women who ranged from 20 to 50 years in age. The alcoholic women were chosen within particular age ranges of women who entered each treatment facility to meet specific aims of the study, which included comparisons of different age groups of alcoholic and nonalcoholic women with an emphasis on identifying psychosocial origins, developmental progression, and consequences of alcoholism in younger women. Adolescents and older women were excluded since the study design called for a comparison of 100 women in their $20 \mathrm{~s}, 100$ women in their $30 \mathrm{~s}$, and 100 women in their $40 \mathrm{~s}$. There was a $7 \%$ refusal rate. ${ }^{1}$

\section{Instrument}

As a first step in determining the internal structure of the consequences of drinking for the alcoholic women, a large set of items was selected to measure drinking-related consequences. These items capture the social and physical effects of heavy drinking as they relate to family, job, peers, and contact with the legal and medical establishment. For these analyses, consequences are defined broadly as drinking-related events, behaviors, situations, effects, or outcomes that the respondent perceives to follow and be the result of her drinking behavior. Seventy-five items, all coded as yes or no, were originally selected for potential inclusion in the composites because they were judged to have good face validity. If the face validity of a certain item was judged as "doubtful," it was included in the first analysis to see whether it loaded or did not load with the more obvious items. Standard criteria calls for 10 subjects optimally and five subjects minimally for every item included in a factor analysis, with four to five times as many variables in the data set as there are underlying factors. ${ }^{32}$ Because of the exploratory, preliminary nature of the analysis, we opted to include more items and thus there are 3.68 items per subject. The analysis does contain, however, more than five times the number of variables compared with underlying factors in accordance with standard criteria.

Items were taken from a variety of sources. Most were drawn from the extensive collection of alcoholism study interview schedules at the Rutgers Center of Alcohol Studies and the literature on female alcoholism. A few came from the Americans View Their Mental Health Study, ${ }^{33}$ which included items based on survey interviews of the Stirling County ${ }^{34}$ and/or Midtown ${ }^{35}$ studies. Finally, a few items came from the Women's Drug Research Study. ${ }^{36}$

A comparison of how frequently "drinking consequence" behaviors occurred when the woman had not been drinking versus when she had been drinking would have been useful, but is not possible because respondents were only queried about the frequency of these behaviors when they had been drinking. Recognizing the conceptual distinction between alcohol dependence and alcohol-related problems, we acknowledge that several items refer to alcohol dependence rather than alcoholrelated problems, e.g., shaking hands, morning drinks, and delirium tremens. An alternative approach might have been to employ a commonly used alcohol dependence questionnaire. However, our questioning of the applicability to women of extant questionnaires, which have been based on research conducted on male samples, guides this research. Moreover, the aim of this factor analytic study is to examine the structure of drinking-related consequences. From this perspective, we argue that the dichotomy between behaviors related to dependence and behaviors related to other aspects of drinking is a false one. Consequently, we chose to include a broad spectrum of alcohol-related behaviors so that consequences that can be directly tied to dependence can be distinguished from other consequences, such as those in the interpersonal and social realms.

Because there are problems in separating consequences from antecedent once a drinking problem has developed, ${ }^{37,38}$ we have attempted to distinguish antecedent from consequence in two ways. First, the respondent herself must perceive the behavior or event to either follow or result from her drinking. Second, most questions have been phrased in such a way that the behaviors or events described are restricted to the time following the development of problem drinking. With these cautions

${ }^{1}$ The study included a control group of 137 nonalcoholic women of similar age, education, and socioeconomic status who were selected by peer nomination. Each clinic woman gave the name of a friend, acquaintance, or neighbor who did not have an alcohol problem. Self-report measures of drinking behavior verified that control women did not have a drinking problem. The questions regarding consequences of alcoholism were not asked of these subjects. 
taken, not all of the items are inherently consequences of drinking, and the causal connection and direction are at best implicit in all the items starting "during the period you were drinking" and "when you first started drinking regularly." There is also the possibility that the wording of these items influenced the factor pattern loadings.

Criteria for inclusion in the composites concerned missing data and skewness. A missing data rule was applied that required $3 / 4$ of the items to be nonmissing for a respondent to be included in the composite, so that the factor analysis was conducted on a reduced total clinic sample of 254. In addition, there was an initial concern because responses from 45 of the 301 alcoholic women, or $15.6 \%$ of the sample, were missing on at least one of the 75 consequence items. The items in question were excluded by listwise deletion from the reliability analyses for both the total clinic sample and sample subgroups before composites were constructed. Accordingly, the $N$ s vary for this series of analyses. We were satisfied that the missing data were not biased, because missing data seemed to be spread out over items. These missing data were not entirely random, however, as there was a slight tendency for respondents with missing data to be older, have later onset, and to report less early acting out. Concerned that valuable information might be lost regarding this subset of cases, missing data were checked. Thirteen cases were recovered by recoding missing data that was due to interviewer error, so that the number of subjects with missing data on the 75 consequences items was reduced to 34 . The composites have been used in analyses which have been reported in other papers. ${ }^{23}$

Obviously certain items are not applicable to certain subjects. We felt that separating such items from the analysis or, alternatively, only analyzing data from subjects who could potentially respond to all of the items, would compromise the substantive integrity of the factors. As an alternative, a respondent was coded as no on an item that was not applicable to her situation. The fact that reliabilities remain consistently high across sample subgroups supports the feasibility of this approach.

None of the items selected for the composites could have serious skewness problems. Two items ("someone died because of respondent's drinking" and "respondent's children were shunned because of drinking") were dropped because of extreme skewness. Another extremely skewed item, "you started to dislike yourself" (skewness $=3.7$ ), was left in because of its obvious relevant conceptual content. Another item (suicide attempts) failed to load on any factor. Three more items were dropped because they lowered reliabilities for the older women in the sample. These items referred to "getting drunk in public places more than once," "gossip about the respondent's immorality," and "loss of temper when drinking or sober." The 69 items that constituted the final data set used for the composites are found in Table 1. Means and standard deviations are presented for each item, as are the prevaience rates of each consequence item among the three age groups.

\section{Analytic Strategies}

Items that were selected for potential inclusion in the composites were submitted to a series of exploratory factor analyses. Factor pattern loadings are reported from the eight factor solution. Items with more than one high loading were resolved by placing the item on the factor with the highest loading. Conceptual considerations also guided the formation of the factors. For example, the fifth factor, accidents, never emerged in the rotations in the form that finally appears in the composites, and some of the items that originally loaded on the eighth factor were removed to form a ninth composite for conceptual clarity. Confirmatory factor analyses with a nine factor solution were conducted to test the appropriateness of these changes and produced essentially the same results with the same factor loadings for the items in the analyses.

\section{RESULTS}

The responses to 73 consequences items were submitted to a series of exploratory principal component analyses, which extracted latent roots greater than 1. This was followed by two rotations that clarified the structure of the underlying dimensions. An orthogonal (varimax) rotation, based on the hypothesis that the underlying dimensions are uncorrelated, was rejected on the basis of the moderately strong intercorrelations between the factors that the nonorthogonal (oblimin) rotation revealed. Accordingly, the oblimin solution is reported here. Factor pattern loadings of 0.3 and above were considered acceptable for inclusion in a composite. Eight factors had eigenvalues exceeding 1.0. The 10 -factor solution, which explained $47 \%$ of the variance, was rejected in favor of the eight-factor solution, which explained $43 \%$ of the variance, because the eight-factor solution demonstrated both parsimony and superior conceptual clarity. ${ }^{39}$ Solutions with a smaller number of factors did not usefully describe the data. For example, we tried a rotation with six factors, which only explained $38 \%$ of the variance. A scree test was conducted that confirmed the selection of the eightfactor solution over these other solutions.

Eight of the nine scales constructed from these items had coefficient alphas ranging from 0.64 to 0.87 , which is above the 0.60 that has been suggested as a minimum acceptable level of internal consistency in exploratory research. ${ }^{32}$ The exception is the illness composite, which is slightly below that level, at 0.57 . The rotated solution is reported in Table 2. Factor pattern loadings, internal reliabilities, and primary factor correlations are reported. Eigenvalues associated with each factor and the percentage of variance accounted for by each factor are also presented.

The nine composites that emerged reflect the different realms of drinking-related consequences reported by alcoholic women in treatment. As can be seen, 18 items loaded more heavily on the first factor. The scale constructed from these items had a coefficient alpha of 0.86 . Labeled social withdrawal, this composite encompasses behavioral items that represent an increasing preoccupation with alcohol, and concomitant withdrawal from nonalcohol-related social spheres.

Seven items loaded on the second factor, and the coefficient alpha for the scale constructed from these items was 0.71 . This second index, called sexuality, describes sexual behavior and perceptions. Ten items loaded on the third factor, early effects, which refers to behaviors and events that occurred when the respondent first began drinking. This composite had a coefficient alpha of 0.87 . Six items loaded on the next two factors, maternal role and accidents, which had coefficient alphas of 0.81 and 0.65 , respectively. Maternal role refers to neglect and difficulties with children, while the accidents factor includes items that describe home and auto accidents and trouble with the police.

The sixth factor, symptoms, describes effects that are directly related to drinking. Three items loaded here with a coefficient alpha of 0.64 . The seventh composite, work, with four items and a coefficient alpha of 0.72 , obviously 
Table 1. Means and Standard Deviations of Items Contained in Consequences Factors and Prevalence of Consequences among Three Age Groups*

\begin{tabular}{|c|c|c|c|c|c|}
\hline & \multirow[b]{2}{*}{ Mean } & \multirow{2}{*}{$\begin{array}{l}\text { Standard } \\
\text { Deviation }\end{array}$} & \multicolumn{3}{|c|}{ Ages } \\
\hline & & & $20-29$ & $30-39$ & $440-59 \dagger$ \\
\hline \multicolumn{6}{|l|}{ Factor 1} \\
\hline \multicolumn{6}{|l|}{$\begin{array}{l}\text { Social withdrawal } \\
\text { ( } 21 \text { items) }\end{array}$} \\
\hline You lost the ability to concentrate. & 2.10 & 1.79 & 75.8 & 73.1 & 68.1 \\
\hline You began to dislike yourself. & 1.24 & 1.95 & 94.9 & 95.4 & 91.5 \\
\hline You began to look awful. & 2.22 & 1.84 & 69.7 & 70.1 & 68.8 \\
\hline You felt sick or crummy most of the time. & 1.97 & 1.72 & 78.8 & 79.6 & 68.1 \\
\hline Friends stopped calling or visiting & 3.70 & 1.88 & 43.4 & 29.9 & $23.9^{* *}$ \\
\hline $\begin{array}{l}\text { Communication with your parents or other } \\
\text { relatives decreased. }\end{array}$ & 2.87 & 1.99 & 74.7 & 54.6 & $28.7^{\star \star}$ \\
\hline $\begin{array}{l}\text { You began to avoid friends who didn't drink } \\
\text { much. }\end{array}$ & 2.75 & 1.99 & 69.7 & 55.6 & $42.6^{* *}$ \\
\hline You lost interest in sex. & 3.36 & 1.97 & 36.7 & 45.8 & 39.8 \\
\hline $\begin{array}{l}\text { You became more and more unbearable to } \\
\text { other people when you were hung over. }\end{array}$ & 2.88 & 2.00 & 60.2 & 52.9 & 45.2 \\
\hline $\begin{array}{l}\text { You telt increasingly lonely and alone and } \\
\text { drank even more. }\end{array}$ & 1.56 & 1.39 & 85.7 & 90.7 & 80.9 \\
\hline $\begin{array}{l}\text { You felt increasingly depressed and drank } \\
\text { even more. }\end{array}$ & 1.28 & 1.02 & 93.9 & 94.4 & 90.3 \\
\hline $\begin{array}{l}\text { You felt as if you were going out of your } \\
\text { mind. }\end{array}$ & 2.24 & 1.85 & 71.7 & 71.3 & 63.4 \\
\hline You began to carry liquor with you. & 2.97 & 2.00 & 63.6 & 47.2 & $41.5^{* \star}$ \\
\hline $\begin{array}{l}\text { You found it increasingly difficult to get } \\
\text { money for liquor. }\end{array}$ & 3.87 & 1.80 & 39.4 & 29.6 & $14.9^{\star \star}$ \\
\hline $\begin{array}{l}\text { Getting rid of the bottles became a prob- } \\
\text { lem. }\end{array}$ & 3.31 & 1.98 & 41.4 & 37.4 & 48.9 \\
\hline $\begin{array}{l}\text { You had trouble making a decision about } \\
\text { anything. }\end{array}$ & 2.22 & 1.85 & 74.7 & 70.4 & 62.8 \\
\hline $\begin{array}{l}\text { You felt very suspicious and distrustful of } \\
\text { other people. }\end{array}$ & 2.47 & 1.93 & 77.8 & 67.6 & $42.6^{\star \star}$ \\
\hline You cut yourself off from old friends. & 2.71 & 1.98 & 69.7 & 50.9 & $51.1^{k *}$ \\
\hline $\begin{array}{l}\text { You saw only a few people, mostly those } \\
\text { you drank with. }\end{array}$ & 2.65 & 1.97 & 73.7 & 56.5 & $45.7^{* \star}$ \\
\hline $\begin{array}{l}\text { Sometimes you wouldn't leave the house at } \\
\text { all except to buy liquor. }\end{array}$ & 2.65 & 1.97 & 55.6 & 64.5 & 55.3 \\
\hline $\begin{array}{l}\text { During the months before you got into } \\
\text { treatment this time, you were feeling very } \\
\text { low and depressed. }\end{array}$ & 2.27 & 1.86 & 90.9 & 89.8 & 82.9 \\
\hline \multicolumn{6}{|l|}{ Factor 2} \\
\hline \multicolumn{6}{|l|}{$\begin{array}{l}\text { Sexuality } \\
\text { (5 items) }\end{array}$} \\
\hline $\begin{array}{l}\text { You got careless about contraception, for- } \\
\text { got to take the pill, etc. }\end{array}$ & 4.24 & 1.57 & 41.4 & 13.1 & $2.2^{* *}$ \\
\hline You felt sexy much more often. & 3.55 & 1.93 & 43.4 & 38.9 & $25.5^{\star}$ \\
\hline $\begin{array}{l}\text { Were you more willing or eager to have sex } \\
\text { when you had been drinking than when you } \\
\text { were sober? }\end{array}$ & 2.88 & 1.99 & 72.7 & 51.0 & $34.1^{\star *}$ \\
\hline $\begin{array}{l}\text { When you had been drinking, did you feel } \\
\text { that you were more sexy to men than when } \\
\text { you were sober? }\end{array}$ & 2.84 & 1.99 & 67.3 & 54.2 & $38.9^{* *}$ \\
\hline $\begin{array}{l}\text { Did you enjoy sex more when you had } \\
\text { been drinking than when you were sober? }\end{array}$ & 3.77 & 1.85 & 36.1 & 34.3 & $20.7^{\star}$ \\
\hline \multirow{2}{*}{\multicolumn{6}{|c|}{$\begin{array}{l}\text { Factor } 3 \\
\text { Early effects } \\
\text { (10 items) }\end{array}$}} \\
\hline & & & & & \\
\hline $\begin{array}{l}\text { When you first started drinking regularly, } \\
\text { were you getting into quarrels with people? }\end{array}$ & 3.48 & 1.94 & 56.6 & 34.3 & $22.3^{* \star}$ \\
\hline $\begin{array}{l}\text { When you first started drinking regularly, } \\
\text { were you losing time from work or school? }\end{array}$ & 4.07 & 1.69 & 48.5 & 18.5 & $2.2^{* \star}$ \\
\hline $\begin{array}{l}\text { When you first started drinking regularly, } \\
\text { were you having blackouts? }\end{array}$ & 3.64 & 1.89 & 60.6 & 28.7 & $11.7^{\star *}$ \\
\hline $\begin{array}{l}\text { When you first started drinking regularly, } \\
\text { were you sneaking drinks or hiding them? }\end{array}$ & 3.67 & 1.89 & 49.5 & 31.5 & $18.3^{* *}$ \\
\hline $\begin{array}{l}\text { When you first started drinking regularly, } \\
\text { were you lying about drinking? }\end{array}$ & 3.50 & 1.94 & 54.5 & 37.0 & $20.2^{* *}$ \\
\hline $\begin{array}{l}\text { When you first started drinking regularly, } \\
\text { were you beginning to drink in the morning? }\end{array}$ & 4.07 & 1.69 & 33.3 & 21.3 & $14.9^{\star \star}$ \\
\hline $\begin{array}{l}\text { When you first started drinking regularly, } \\
\text { were you driving the car while drunk? }\end{array}$ & 3.18 & 1.99 & 67.7 & 45.4 & $22.3^{* *}$ \\
\hline $\begin{array}{l}\text { When you first started drinking regularly, } \\
\text { were you taking pills in the morning to get } \\
\text { going? }\end{array}$ & 4,09 & 1.67 & 42.4 & 16.7 & $8.5^{* *}$ \\
\hline
\end{tabular}


Table 1. Continued

\begin{tabular}{|c|c|c|c|c|c|}
\hline & \multirow[b]{2}{*}{ Mean } & \multirow{2}{*}{$\begin{array}{l}\text { Standard } \\
\text { Deviation }\end{array}$} & \multicolumn{3}{|c|}{ Ages } \\
\hline & & & $20-29$ & $30-39$ & $40-59 \dagger$ \\
\hline $\begin{array}{l}\text { When you first started drinking regularly, } \\
\text { were you drinking alone? }\end{array}$ & 3.19 & 1.99 & 57.6 & 46.3 & $30.9^{* *}$ \\
\hline $\begin{array}{l}\text { When you first started drinking regularly, } \\
\text { was someone close to you acting con- } \\
\text { cerned about your drinking? }\end{array}$ & 3.43 & 1.96 & 57.6 & 35.2 & $24.5^{\star \star}$ \\
\hline \multicolumn{6}{|l|}{ Factor 4} \\
\hline \multicolumn{6}{|l|}{$\begin{array}{l}\text { Maternal role } \\
(6 \text { items) }\end{array}$} \\
\hline $\begin{array}{l}\text { You had trouble taking good care of your } \\
\text { children. }\end{array}$ & 3.71 & 1.87 & 13.1 & 43.5 & $39.4^{\star *}$ \\
\hline You lost communication with your children. & 3.71 & 1.87 & 9.1 & 41.7 & $46.2^{* \star}$ \\
\hline You set a bad example for your children. & 2.87 & 1.99 & 17.2 & 63.0 & $79.8^{\star \star}$ \\
\hline $\begin{array}{l}\text { You'd make plans with the children and } \\
\text { couldn't carry them out. }\end{array}$ & 3.59 & 1.91 & 15.2 & 47.2 & $42.6^{\star \star}$ \\
\hline There was a threat to take the children & 4.39 & 1.44 & 10.1 & 25.0 & $9.6^{* *}$ \\
\hline away from you. & & & & & \\
\hline $\begin{array}{l}\text { During the months before you stopped } \\
\text { drinking and got into treatment this time, } \\
\text { you were having problems with one of your } \\
\text { children. }\end{array}$ & 4.37 & 1.46 & 10.1 & 35.2 & $44.1^{* *}$ \\
\hline \multirow{2}{*}{\multicolumn{6}{|c|}{$\begin{array}{l}\text { Factor } 5 \\
\text { Accidents }\end{array}$}} \\
\hline & & & & & \\
\hline \multicolumn{6}{|l|}{ (6 items) } \\
\hline You had an auto accident. & 3.63 & 1.90 & 46.5 & 31.5 & $24.5^{\star \star}$ \\
\hline You had more than one accident at home. & 3.60 & 1.91 & 45.5 & 30.6 & $28.7^{\star}$ \\
\hline You were arrested. & 3.88 & 1.80 & 42.4 & 20.4 & $21.3^{* *}$ \\
\hline $\begin{array}{l}\text { During the period while you were drinking, } \\
\text { there was gossip that you were a "drunk." }\end{array}$ & 3.09 & 2.00 & 53.7 & 47.7 & 41.8 \\
\hline $\begin{array}{l}\text { During the months before you stopped } \\
\text { drinking and got into treatment this time, } \\
\text { you got into trouble with the police. }\end{array}$ & 4.19 & 1.61 & 33.3 & 13.9 & $17.2^{\star \star}$ \\
\hline $\begin{array}{l}\text { During the months before you stopped } \\
\text { drinking and got into treatment this time, } \\
\text { something happened that was very disturb- } \\
\text { ing. }\end{array}$ & 3.94 & 1.77 & 53.5 & 50.5 & 49.5 \\
\hline \multicolumn{6}{|l|}{ Factor 6} \\
\hline \multicolumn{6}{|l|}{$\begin{array}{l}\text { Symptoms/effects } \\
\text { ( } 5 \text { items) }\end{array}$} \\
\hline $\begin{array}{l}\text { When you first started drinking regularly, } \\
\text { were you having hangovers? }\end{array}$ & 2.59 & 1.96 & 73.7 & 62.0 & $44.1^{\star \star}$ \\
\hline $\begin{array}{l}\text { You couldn't account for some periods of } \\
\text { time. }\end{array}$ & 1.75 & 1.56 & 89.9 & 73.1 & $81.7^{\star \star}$ \\
\hline $\begin{array}{l}\text { You found bruises on yourself and couldn't } \\
\text { remember how you got them. }\end{array}$ & 1.93 & 1.69 & 86.9 & 67.6 & 76.6 \\
\hline $\begin{array}{l}\text { You noticed that your hands shook when } \\
\text { you tried to pick something up. }\end{array}$ & 2.12 & 1.80 & 73.7 & 69.4 & 73.4 \\
\hline $\begin{array}{l}\text { You had increasing trouble with blackouts, } \\
\text { DTs, shakiness, or passing out a lot. }\end{array}$ & 2.31 & 1.88 & 76.5 & 60.2 & $65.6^{*}$ \\
\hline Factor 7 & & & & & \\
\hline \multicolumn{6}{|l|}{ Work problems } \\
\hline You began losing time at work. & 3.47 & 1.95 & 51.5 & 38.0 & $24.7^{\star \star}$ \\
\hline You got warnings at work. & 3.97 & 1.75 & 38.4 & 22.2 & $16.3^{\star \star}$ \\
\hline You had other trouble at work. & 4.01 & 1.73 & 37.4 & 21.3 & $15.1^{\star \star}$ \\
\hline $\begin{array}{l}\text { You were warned that you might lose your } \\
\text { job. }\end{array}$ & 4.40 & 1.43 & 22.4 & 15.0 & 12.2 \\
\hline \multicolumn{6}{|l|}{ Factor 8} \\
\hline IIIness & & & & & \\
\hline \multicolumn{6}{|l|}{ (5 items) } \\
\hline $\begin{array}{l}\text { You had to go to the emergency room at } \\
\text { the hospital. }\end{array}$ & 3.31 & 1.98 & 44.4 & 43.5 & 38.3 \\
\hline $\begin{array}{l}\text { You were hospitalized because of illness re- } \\
\text { lated to drinking. }\end{array}$ & 3.66 & 1.89 & 31.3 & 36.2 & 33.0 \\
\hline You experienced hallucinations. & 4.06 & 1.70 & 25.5 & 23.1 & 21.5 \\
\hline $\begin{array}{l}\text { You began needing a drink when you got } \\
\text { up in the morning. }\end{array}$ & 2.73 & 1.98 & 50.5 & 58.3 & 61.7 \\
\hline You had a pretty serious illness. & 4.40 & 1.43 & 25.3 & 26.9 & 18.3 \\
\hline \multicolumn{6}{|l|}{ Factor 9} \\
\hline \multicolumn{6}{|l|}{ Relationship conflicts } \\
\hline $\begin{array}{l}\text { You began having serious quarrels with the } \\
\text { family-husband, children, your parents- } \\
\text { because of your drinking. }\end{array}$ & 2.26 & 1.86 & 72.7 & 71.3 & $60.6^{*}$ \\
\hline
\end{tabular}


Table 1. Continued

\begin{tabular}{|c|c|c|c|c|c|}
\hline & \multirow[b]{2}{*}{ Mean } & \multirow{2}{*}{$\begin{array}{l}\text { Standard } \\
\text { Deviation }\end{array}$} & \multicolumn{3}{|c|}{ Ages } \\
\hline & & & $20-29$ & $30-39$ & $40-59 \dagger$ \\
\hline $\begin{array}{l}\text { People you knew asked you to stop drink- } \\
\text { ing. }\end{array}$ & 1.91 & 1.68 & 76.8 & 78.7 & 76.3 \\
\hline $\begin{array}{l}\text { Your husband or boyfriend threatened to } \\
\text { leave. }\end{array}$ & 3.32 & 1.98 & 53.5 & 44.4 & $26.6^{* *}$ \\
\hline $\begin{array}{l}\text { While you were drinking, your family or } \\
\text { friends became critical or angry at you. }\end{array}$ & 2.14 & 1.81 & 69.7 & 74.1 & 70.2 \\
\hline $\begin{array}{l}\text { During the months before you stopped } \\
\text { drinking and got into treatment this time, } \\
\text { you were having marriage or love problems. }\end{array}$ & 3.37 & 1.97 & 61.6 & 72.2 & 62.4 \\
\hline $\begin{array}{l}\text { During the months before you stopped } \\
\text { drinking and got into treatment this time, } \\
\text { husband or relatives got fed up with you. }\end{array}$ & 2.95 & 2.00 & 55.6 & 59.3 & 42.4 \\
\hline
\end{tabular}

- Prevalence figures are represented by percentages. For items in Factors 4 (Maternal Role) and 7 (Work Problems), percentages are not calculated on the entire sample. Childless and unemployed women are excluded from the calculation of these items.

$+p \leq 0.05 ;{ }^{* *} p<0.01$

refers to work-related problems. Four items loaded on the eighth factor, illness, which had the lowest coefficient alpha of 0.57. Items on this index include visits to hospitals, to emergency rooms, illness, and hallucinations. The ninth, relationship conflict, had six items and a coefficient alpha of 0.71 . It reflects difficulties in primary relationships.

Eleven items loaded on more than one factor. They were: people seemed critical, avoid friends, suspicious and distrustful, gossip you're a drunk, quarrels, lose time from work or school, blackouts, driving the car drunk, taking pills in the morning, auto accident, and needed a drink in the morning. Items that loaded on more than one factor were resolved conceptually; in each case the factor loading was higher on the selected factor. While items that load on more than one factor are less useful in constructing a measure than items that load on a single factor, the factors do meet the criteria suggested by Kim and Mueller $(1978)^{39}$ that at least three variables clearly load on each factor so that the simple structure can be identified unambiguously.

A final set of analyses was conducted by age group to determine whether the internal consistency of the factors was similar for the age subgroups of alcoholic women. Reliabilities for different age groups in the sample are reported in Table 3 . The reader will note that the $N$ 's vary for each of the composites because cases with missing data were excluded from the reliability analyses for the subgroups. For the most part, the coefficient alphas remained sufficiently high and similar across subgroups. Most internal reliability measures are in the 0.6 to 0.8 range.

The only exceptions to the pattern of high internal reliability coefficients among the subgroups of alcoholic women are found on the maternal role, accidents, and symptoms/effects composites. These lower coefficient alphas indicate that the items on the index were not endorsed consistently. Lower alpha coefficients, in the 0.5 range, are found on the maternal role and accidents composites for the older women, and on the symptoms/effects composite for the youngest and oldest subgroups. These lower alpha coefficients suggest that these different age groups do not consistently endorse all of the items on the composite; rather, they endorse certain items, but not others. The consistently lower internal reliabilities on the illness composite, which are in the 0.5- to 0.6-range in all analyses, may be a result of the few items that loaded on this composite.

\section{DISCUSSION}

This paper has examined the structure of drinkingrelated consequences in a sample of alcoholic women by submitting self-reported consequences to a series of exploratory factor analyses. Nine composites were constructed to represent the different domains of adverse consequences as they relate to social isolation, sexual behavior, early and later symptoms or effects, motherhood, accidents, work, medical problems, and interpersonal relationships. The majority of coefficient alphas remained sufficiently high and similar across subgroups, indicating a cohesive structure among the consequence items, with minimal differences among age groups.

For conceptual clarity, conclusions must necessarily be limited to the comparable inter-item consistency of the consequences factors for the three age groups as similar degrees of internal reliability of drinking consequences factors across age groups do not mean that there are no differences in the levels of consequences experienced by different age groups of women. On the contrary, as shown in Table 1, the prevalence of the various consequence items varies significantly for many of the items for the three age groups. Two groups can have different absolute levels of consequences, but still have the same patterns of inter-item correlations among consequences.

Differences in the structure of consequences among different age groups of alcoholic women emerged on the maternal role and accidents composites for the older women, and on the symptoms/effects composite for the youngest and oldest subgroups. It may be that older women did not consistently report items on the maternal 
Table 2. Consequences Composites: Factor Pattern Loadings, Internal Reliabilities, and Primary Factor Correlations

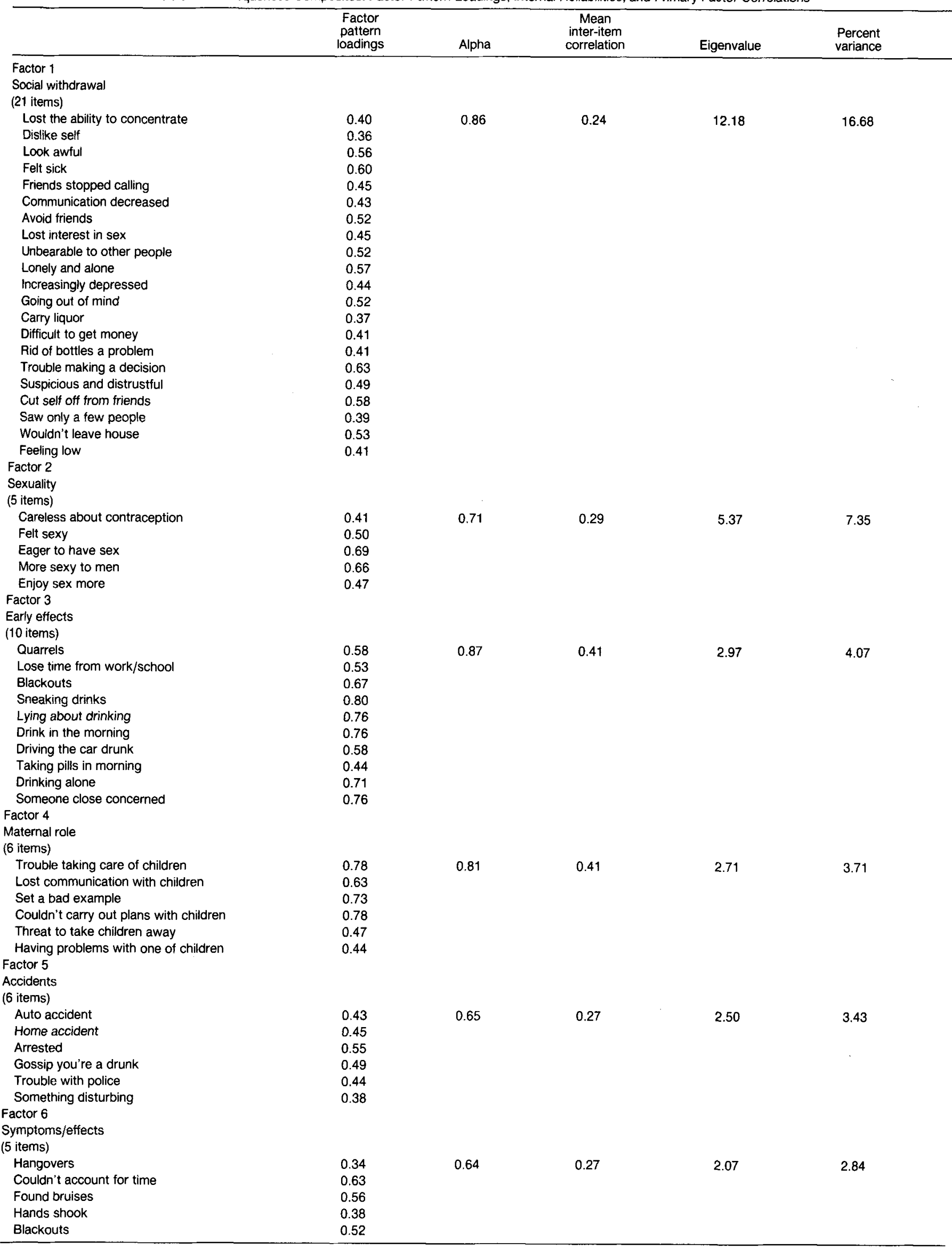


Table 2. Continued

\begin{tabular}{|c|c|c|c|c|c|}
\hline & $\begin{array}{c}\text { Factor } \\
\text { pattern } \\
\text { loadings }\end{array}$ & Alpha & $\begin{array}{c}\text { Mean } \\
\text { inter-item } \\
\text { correlation }\end{array}$ & Eigenvalue & $\begin{array}{l}\text { Percent } \\
\text { variance }\end{array}$ \\
\hline \multicolumn{6}{|l|}{ Factor 7} \\
\hline \multicolumn{6}{|l|}{$\begin{array}{l}\text { Work problems } \\
\text { (4 items) }\end{array}$} \\
\hline Lost time & 0.60 & 0.72 & 0.39 & 1.78 & 2.44 \\
\hline Got warnings & 0.75 & & & & \\
\hline Other trouble & 0.54 & & & & \\
\hline Warned might lose job & 0.47 & & & & \\
\hline \multicolumn{6}{|l|}{ Factor 8} \\
\hline \multicolumn{6}{|l|}{ Illiness } \\
\hline \multicolumn{6}{|l|}{ (5 items) } \\
\hline Emergency room & 0.44 & 0.57 & 0.21 & 1.77 & 2.42 \\
\hline Hospitalized & 0.53 & & & & \\
\hline Hallucinations & 0.38 & & & & \\
\hline Needed a drink in morning & 0.48 & & & & \\
\hline Serious illness & 0.43 & & & & \\
\hline \multicolumn{6}{|l|}{ Factor 9} \\
\hline \multicolumn{6}{|l|}{ Relationship conflicts } \\
\hline \multicolumn{6}{|l|}{ (7 items) } \\
\hline Serious quarrels with family & 0.48 & 0.71 & 0.26 & 1.68 & 2.31 \\
\hline People asked you to stop drinking & 0.54 & & & & \\
\hline Husband or boyfriend threatened to leave & 0.62 & & & & \\
\hline People seemed critical & 0.39 & & & & \\
\hline Family or friends critical & 0.54 & & & & \\
\hline Marriage or love problems & 0.44 & & & & \\
\hline Husband or relatives fed up & 0.62 & & & & \\
\hline
\end{tabular}

Table 3. Cronbach Alphas for Consequences Composites for Groups of Cases

\begin{tabular}{|c|c|c|c|c|c|c|c|c|c|c|c|c|c|c|c|c|c|c|}
\hline & \multicolumn{2}{|c|}{$\begin{array}{l}\text { Social with- } \\
\text { drawal }\end{array}$} & \multicolumn{2}{|c|}{ Sexuality } & \multicolumn{2}{|c|}{$\begin{array}{c}\text { Early } \\
\text { effects }\end{array}$} & \multicolumn{2}{|c|}{$\begin{array}{l}\text { Maternal } \\
\text { role }\end{array}$} & \multicolumn{2}{|c|}{ Accidents } & \multicolumn{2}{|c|}{$\begin{array}{l}\text { Symp- } \\
\text { toms/ } \\
\text { effects }\end{array}$} & \multicolumn{2}{|c|}{ Work } & \multicolumn{2}{|c|}{ Illness } & \multicolumn{2}{|c|}{$\begin{array}{l}\text { Rela- } \\
\text { tionship } \\
\text { conflict }\end{array}$} \\
\hline & $N$ & & $N$ & & $N$ & & $N$ & & $N$ & & $N$ & & $N$ & & $N$ & & $N$ & \\
\hline All & 286 & 0.86 & 291 & 0.71 & 301 & 0.87 & 299 & 0.81 & 299 & 0.65 & 297 & 0.64 & 300 & 0.72 & 297 & 0.57 & 297 & 0.71 \\
\hline $20-29$ Years & 96 & 0.88 & 96 & 0.68 & 99 & 0.82 & 99 & 0.92 & 99 & 0.66 & 98 & 0.53 & 99 & 0.70 & 99 & 0.56 & 99 & 0.71 \\
\hline $30-39$ Years & 102 & 0.85 & 105 & 0.67 & 108 & 0.84 & 108 & 0.82 & 107 & 0.65 & 108 & 0.71 & 108 & 0.70 & 106 & 0.59 & 107 & 0.76 \\
\hline 40-56 Years & 88 & 0.85 & 90 & 0.61 & 94 & 0.88 & 92 & 0.59 & 93 & 0.52 & 91 & 0.56 & 93 & 0.70 & 92 & 0.57 & 91 & 0.62 \\
\hline
\end{tabular}

role composite because their drinking problem was less severe during their child rearing years. It may also be related to differences in percentages of those who have children. Only $22 \%$ of the youngest group of women have had children, compared with $70 \%$ of those in their 30 s and $95 \%$ of the women in their 40 s who have been mothers. Other analyses of these data have shown that there is a great deal of guilt and anxiety associated with the maternal role with indications that the guilt and anxiety are greatest among the middle-aged women. The express ways in which these differences are related to the observed differences in response to maternal role items is not clear, but they apparently influence the outcome. Similarly, age differences in patterns of drinking, at least public versus private drinking, might play a role in the accidents factor. Asked about drinking in public places like bars, lounges, and nightclubs, twice as many young women as older women responded affirmatively. Seventyone percent of the women in their 20 s reported drinking in public places like bars, whereas only $34 \%$ of the women in their 40 s reported public drinking. Of the six items in the accidents factor, five related to visible drinking and only one related to accidents at home. While a possible interpretation to these age differences might center on memory bias, age-related memory bias has not been supported by research. ${ }^{40}$

Because this is an exploratory study, it has certain limitations which should be addressed in future analyses. First, this study examines a clinical population, which limits the generalizability of the findings. Studies that go beyond the boundaries of the treatment setting and into the community are not only able to elucidate barriers to care, but provide knowledge about people with less severe alcohol problems. Second, this study includes a potentially restricted range of responses on each when compared with all those in the population at large who would report any of these items. In a broader population, for example, there might well be a tendency for the items to load onto a single, general factor. Such analyses are beyond the scope of this paper, but in recognition of these limitations, the senior author is currently conducting analyses using data from the Epidemiologic Catchment Area (ECA), ${ }^{41}$ which should yield valuable information in this regard. ${ }^{42}$ Our purpose here is to contribute toward a greater understanding of how the woman alcoholic presents herself in a treatment facility, with the hope of improving rehabilitation and treatment. Another of our objectives in studying the drinking-related consequences of the sample of alco- 
holic women is to derive a severity score for each woman. The items that make up the nine factors form the basis for individual alcoholism severity scores; the relationship between these scores and a number of other variables will be investigated.

Another consideration is the use of dichotomous variables. Most researchers do not consider dichotomous variables optimal for a factor analysis, believing that items scored on an interval, i.e., Likert-type scale, are preferable. However, the use of dichotomous variables has been addressed in the empirical literature on factor analysis. ${ }^{39,43-45}$ This analysis differs from the usual factor analysis in the following ways. Factor pattern loadings of 0.4 and above are standard acceptable criteria for inclusion and because of the exploratory nature of this study, we have included several items in the 0.3 range. Finally, because the alpha is influenced by the number of items in a factor, the high alphas associated with factor 1 may be a reflection of the large number of items that were included.

When the extant literature is integrated with the present findings, intriguing future analyses are suggested. For example, the findings of MacAndrew's factor analytic study suggest that female alcoholics may not differ from other distressed women on certain behaviors. ${ }^{15}$ Further analyses are needed to examine areas of similarity between different diagnostic categories. Other analyses may find differences among alcoholic women. Women alcoholics, for example, may be distinguished on whether or not their drinking and sexuality are bound together. Similarly, analyses on demographic characteristics, such as parental status, working status, or certain classes of events or illnesses would make interesting and potentially useful analyses. Research in this area would add to the findings of genetic studies, which have begun to provide evidence for different typologies of alcoholism, ${ }^{46}$ but have yet to unravel the relative contribution of inherited and environmental factors completely. Finally, analyses that focus on the methodological aspects of this study may prove useful because of the moderate to minimally acceptable alphas for several of the composites. Different methods of factor analysis have been addressed in the literature over the past decade, ${ }^{47-49}$ and recent research indicates that principal axis factor analysis is preferable to principal component analyses. ${ }^{50}$ For these reasons, comparative analysis in a new sample would be useful.

Alcohol-related consequences are critical to understanding the course of alcoholism. For example, adverse consequences of drinking have been identified as predictors of aggression, ${ }^{51}$ help-seeking, ${ }^{52}$ and long-term abstinence. ${ }^{53}$ Further, research has shown that psychiatric disorders may be aggravated by the social consequences of substance abuse. ${ }^{54}$ Research is beginning to show that specific consequences vary widely among different populations. For example, social problems directly related to drinking are associated with certain psychiatric diagnoses, i.e., antisocial personality, ${ }^{55}$ but not others, i.e., major depres- sion. ${ }^{25,56,57}$ The argument for consequences scales that are based on the unique experience of subpopulations of alcoholics is bolstered by the preliminary evidence from studies that indicate variations in the physical and social consequences among different ethnic groups for both men and women ${ }^{58,59}$ building on earlier work that ties specific consequences to socioeconomic status. ${ }^{9}$

In the past, consequences have been defined by male samples and, therefore, have been based on problems that men experience. These findings may or may not be relevant for women. Gender differences in self-report are well known, and studies show clear differences in the prevalence of female and male drinkers who report alcoholrelated social consequences. ${ }^{3,60}$ There are also differences between men and women regarding proneness to liver disorder, differences in legal consequences, and differences within each sex of consequences of younger and older alcoholics. ${ }^{61,62}$ Clearly, a consensual definition of the consequences experiences by female drinkers is needed for future alcohol research. The establishment of these composites is an initial step in that direction.

\section{REFERENCES}

1. Williams KH: Medical consequences of alcoholism. Ann Int Med 81(2):265, 1974

2. Hill SY: Vulnerability to the biomedical consequences of alcoholism and alcohol-related problems among women, in Wilsnack SC, Beckman LJ (eds): Alcohol Problems in Women: Antecedents, Consequences, and Intervention. New York, The Guilford Press, 1984, pp 121-154

3. Clark WB, Midanik L: Alcohol use and alcohol problems among U.S. adults: Results of the 1979 survey, Alcohol Consumption and Related Problems. Alcohol and Health Mongraph No. 1, DHHS Pub. No. (ADM) 82-1190, Washington, DC, Superintendent of Documents, US Government Printing Office, 1982, pp 3-52

4. Gomberg ESL: Alcoholism in women, in Kissin B, Begleiter $\mathrm{H}$ (eds): Social Aspects of Alcoholism, Vol. IV. New York, Plenum, 1976, pp 117-166

5. Wilsnack SC, Wilsnack RW, Klassen AD: Drinking and drinking problems among women in a U.S. national survey. Alcohol Health Res World, Winter: 4-13, 1984

6. Wilsnack SC, Wilsnack RW, Klassen AD: Women's drinking and drinking problems: Patterns from a 1981 national survey. Am J Public Health 74:1231-1238, 1984

7. Beckman LJ: Alcoholism problems in women and children: An overview, in Greenblatt M \& Schuckit M (eds): Alcoholism Problems in Women and Children, New York, Grune and Stratton, 1976

8. Curlee JA: A comparison of male and female patients at an alcoholism treatment center. J Psychol 74:239-247, 1970

9. Lisanky E: Alcoholism in women: Social and psychological concomitants. Social history data. Q J Stud Alcohol 18:588-623, 1957

10. Beck AT, Lester D: Components of depression in attempted suicides. J Psychol 85:257-260, 1973

11. Gibson W, Becker J: Alcoholism and depression: The factor structure of alcoholics' responses to depression interventions. Q J Stud Aicohol 34:400-408, 1973

12. Steer RA, Shaw BF, Beck AT, Fine AW: Structure of depression in black alcoholic men. Psychol Rep 41:1235-1241, 1977

13. Steer RA, McElroy MG, Beck AT: Correlates of self-reported and clinically assessed depression in outpatient alcoholics. J Clin Psychol 39:144-148, 1983

14. Turnbull JE, Gomberg ESL: The structure of depression in alcoholic women. J Stud Alcohol 51(6): January 1990

15. McAndrew C: Similarity in self-depictions of female alcoholics 
and psychiatric outpatients: Examination of Eysenck's dimension of emotionality in women. J Stud Alcohol 47(6):478-484, 1986

16. Hathaway SR, McKinley JC: A multiphasic personality schedule (Minnesota): I. Construction of the schedule. J Psychol 10:249-254, 1940

17. Hilton ME: Drinking patterns and drinking problems in 1984: Results from a general population survey. Alcohol Clin Exp Res 11(2):167-175, 1984

18. Dahlgren L, Myhred M: Female alcoholics. II. Causes of death with reference to sex difference. Acta Psychiatr Scand 56:81-897, 1977

19. Medhus A: Mortality among female alcoholics. Scand J Soc Med 3:111-115, 1975

20. Schmidt W, Popham RE: Heavy alcohol consumption and physical health problems: A review of the epidemiological evidence. Drug Alcohol Depend 1:27-50, 1976

21. Dahlgren L, Idestrom CM: Female alcoholics. V. Morbidity. Acta Psychiatr Scand 60:199-213, 1979

22. Ashley M, Olin J, Le-Riche W, Kornaczewski A, Schmidt W, Rankin JG: Morbidity in alcoholics: Evidence for accelerated development of physical disease in women. Arch Int Med 137:883-887, 1977

23. Turnbull JE, Gomberg ESL: Impact of depressive symptomatology on alcohol problems in women. Alcohol Clin Exp Res (12)3:374381,1988

24. Vaillant GE, Gale L, Milofsky ES: Natural history of male alcoholism: II. The relationship between different diagnostic dimensions. J Stud Alcohol 43(3):216-232, 1982

25. Hesselbrock VM, Stabenau JR, Hesselbrock MN, Meyer RE, Babor TF: The nature of alcoholism in patients with different family histories for alcoholism. Progress in Neuropsychopharmacol Biol Psychiatry 2(4-6):607-614, 1982

26. Hesselbrock VM, Hesselbrock MN, Stabenau JR: Alcoholism in patients subtyped by family history for antisocial personality. J Stud Alcohol 46(1):59-64, 1985

27. Schuckit M, Winokur G: A short-term follow-up of women alcoholics. Dis Nerv System 33:672-678, 1973

28. Pottinger N, McKernon J, Patrie L, Weissman M, Ruben H, Neubury P: The frequency of persistence of depressive symptoms in the alcohol abuser. J Nerv Ment Dis 166:562-569, 1978

29. Cushman P, Dorus W, Schaefer M: Correlation of social stability and depression in alcoholics. Alcohol Clin Exp Res 1:94, 1986

30. McMahon RC, Davidson RS: An examination of depressed vs. nondepressed alcoholics in inpatient treatment. J Clin Psychol 42:177184,1986

31. Fowler RC, Liskow BI, Tanna VL: Alcoholism, depression, and life events. J Affective Disord 2:127-135, 1980

32. Nunnally J: Psychometric Theory, ed 2. New York, McGraw Hill, 1978

33. Veroff J, Douvan E, Kulka R: The Inner American: A SelfPortrait from 1957-1976. New York, Basic Books, 1981

34. MacMillan AM: The health opinion survey: Technique for estimating prevalence of psychoneurotic and related types of disorder in communities. Psychol Rep 3:325-339, 1957

35. Srole L, Langner TS, Michael S, Opler MK, Rennie TAC: Mental Health in the Metropolis. New York, McGraw-Hill, 1962

36. NIDA, Grant H811 DA 01496-03: Women's Drug Research Project. Report on comparative analyses of psychosocial variables: Self perceptions and attitudes, social supports, and family backgrounds of heroin addicted women, 1977

37. Gomberg ESL: Risk factors related to alcohol problems among women: Proneness and vulnerability, Alcoholism and Alcohol Abuse Among Women: Proneness and vulnerability. Research Monograph No. 1, NIAAA, 1978

38. Wolin S: Psychosocial consequences of alcohol for women, $A l-$ coholism and Alcohol Abuse Among Women: Research Issues. Research Monograph No. 1, NIAAA, 1978

39. Kim J, Mueller C: Introduction to Factor Analysis and Factor
Analysis: Statistical Methods and Practical Issues. Beverly Hills, Sage Publications, 1978

40. Herzog AR, Diehlman L: Age in differences in response accuracy for factual survey questions. J Gerontol 40(3):350-357, 1985

41. Regier DA, Myers JK, Kramer M, Robins LN, Blazer DG, Eaton

WW, Locke BZ: The Epidemiologic Catchment Area Program. Arch Gen Psychiatry 41:934-941, 1985

42. Turnbull JE, Habib KM, Landerman R: Similarities in symptom profiles among alcoholic men and women. Alcohol Clin Exp Res 14(2):338, 1990

43. Mooijaart, A: Two kinds of factor analysis for ordered categorical variables. Multivar Behav Res 18:423-441, 1983

44. Muten B: Contributions to factor analysis of dichotomous variables. Psychometrika 43:551-560, 1978

45. Muten B, Christoffersson A: Simultaneous factor analysis of dichotomous variables in several groups. Psychometrika 46:407-420, 1981

46. Cloninger CR, Sigvardsson S, Von Knorring AL, Bohman $M$ : The Swedish studies of the adopted children of alcoholics: A reply to Littrell. J Stud Alcohol 49(6):500-509, 1988

47. Acito F, Anderson RD: A Monte Carlo comparison of factor analytic methods. J Marketing Res 17:228-236, 1980

48. Borgatta EF, Kercher K, Stull DE: A cautionary note on the use of principal components analysis. Soc Meth Res 15:160-168, 1986

49. Hubbard R, Allen SJ: A cautionary note on the use of principal components analysis: Supportive empirical evidence. Soc Meth Res 16:301-308, 1987

50. Snook RC, Gorsuch RL: Component analysis vs. common factor analysis: A Monte Carlo study. Psychol Bull 106:148-154, 1989

51. Leonard KE: Patterns of alcohol use and physically aggressive behavior in men. J Stud Alcohol 46(4):279-282, 1985

52. Hingson R, Mangione T, Meyers AR, Scotch N: Seeking help for drinking problems: A study in the Boston metropolitan area. J Stud Alcohol 43(3):273-288, 1982

53. Nordstrom G, Berglund M: Successful adjustment in alcoholism: Relationships between causes of improvement, personality, and social factors. J Nerv Ment Dis 174(11):664-668, 1986

54. O'Brien CP, Woody GE, McLellan AT: Psychiatric disorders in opioid-dependent patients. J Clin Psychiatry 45(12):9-13, 1984

55. Robins LN, Helzer JE, Ratcliff KS, Seyfried W: Validity of the Diagnostic Interview Schedule Version II: DSM-III diagnoses. Psychol Med 12:855-870, 1982

56. Hesselbrock MN, Meyer R, Kenner JJ: Psychopathology in hospitalized alcoholics. Arch Gen Psychiatry 42:1050-1055, 1985

57. Hasin D, Grant B, Endicott J; Treated and untreated suicide attempts in substance abuse patients. J Nerv Ment Dis 176:289-294, 1988

58. Panitz DR, McConchie RD, Sauber SR, Fonseca JA: The role of machismo and the Hispanic family in the etiology and treatment of alcoholism in Hispanic American males. Am J Family Ther 11(1):3144,1983

59. Malin HJ, Archer LD, Munch NE: A national surveillance system for alcoholism and alcohol abuse. Paper presented at the 32nd International Congress on Alcoholism and Drug Dependence, Warsaw, Poland, September 3-8, 1978. (Alcohol Epidemiologic Data System Working Paper No. 8, Rockville, MD)

60. Calahan D: Ethnoreligious group differences, 1974 drinking survey. (Supplement to Calahan D, et al., Alcohol Problems and Their Prevention: Public Attitudes in California). Berkeley, California, Social Research Group, School of Public Health, University of California, Berkeley, 1976

61. Gomberg ESL: The young male alcoholic: A pilot study. J Stud Alcohol 43:683-701, 1982

62. Gomberg ESL: Women and alcoholism: Psychosocial issues: Women and Alcohol: Health-Related Issues. Research Monograph 16, NIAAA DHHS Publ. No. (ADM) 86-1139, 1986 